\title{
Introducing peer support work in Latin American mental health services
}

\author{
Introduzindo o trabalho de pares nos serviços de saúde mental da
} América Latina

Peter Stastny ${ }^{1}$

\begin{abstract}
In the course of implementing a recently funded network of hubs for building capacities in mental health service development, training, and research (RedeAmericas), the peer support workers are being introduced into the mental health workforce in three Latin American countries for the very first time. They will be part of a team, along with community mental health workers, that provides a modified Critical Time Intervention to individuals with severe psychiatric disorders living in the community. This article reviewed the background of this increasingly widespread development, and discussed its merits, as well as potential obstacles within local contexts.
\end{abstract}

Keywords: social support; schizophrenia; mental health.

\section{Resumo}

No decorrer da implementação de uma rede recentemente financiada para realizar capacitações na formação de profissionais, na pesquisa e no aprimoramento dos serviços de saúde mental na América Latina (RedeAmericas), os trabalhadores de apoio de pares estão sendo introduzidos na força de trabalho da saúde mental em três países latino-americanos pela primeira vez. Tais profissionais farão parte de uma equipe, juntamente com agentes comunitários de saúde mental, que fornece uma intervenção no período crítico, adaptada para indivíduos com transtornos psiquiátricos graves residentes na comunidade. Este artigo revisou o conhecimento prévio desta intervenção cada vez mais difundida e discutiu seus méritos, assim como os potenciais obstáculos nos contextos locais.

Palavras-chave: apoio social; saúde mental; esquizofrenia. 


\section{BACKGROUND (WHY PEER WORKERS?)}

It has long been recognized in community healthcare that the employment of lay community members helps building connections between clinic and community ${ }^{1-3}$, as well as enhancing the well-being of service recipients, at least for certain medical conditions $s^{4}$. Methods for recruiting and training workers diagnosed with severe mental disorders and/or experiences as service users have now been widely developed, and roles for peer support workers (PSWs) different from those of lay community mental health workers (CMHWs) have been defined and, in turn, can provide such workers with equal status and salaries ${ }^{5,6}$. Among Latin American countries, Brazil has been a pioneer in the area of mental health reform for the past 20 years, with an enormous amount of grassroots organizing experience and conceptual work on the significance of advocacy and community organizations ${ }^{7,8}$. Chile has also made substantial strides in developing a sophisticated community mental health system, with special emphasis on its linkages to primary care services ${ }^{9}$. However, neither country has made a significant headway in integrating former patients as providers.

The concept of peer support is based on the notion that people who have experienced and overcome a particular type of adversity can be useful sources of support, encouragement, and hope to others experiencing similar situations ${ }^{10}$. This tenet has been widely accepted in the substance abuse field, in which former users are increasingly assuming important roles as expert service providers and administrators of rehabilitation and recovery programs ${ }^{11}$. In mental health, the idea of integrating consumer/ex-patients into the workforce has led to large array of ventures in many countries. Thousands of former patients have become employed in the past two decades, who might otherwise have remained on the rolls of disability pensions ${ }^{1}$. For example, a survey of consumer perspectives on the management of psychiatric emergencies identified peer support as a future priority to use in emergency settings ${ }^{12}$. Among other areas, peer support has become an important element in crisis management, be that in traditional emergency services ${ }^{13}$, inpatient units ${ }^{14}$, during the aftermath of disasters ${ }^{15}$, or in crisis residential settings, including peer-run alternatives to hospitalization ${ }^{16-18}$. Recently, several research projects have focused on the importance of peer support in the transition from hospital to community. Currently, one pilot study in Australia has been investigating the impact of peer support following discharge from a specialist first-episode psychosis treatment center ${ }^{19}$.
PSWs have successfully become integrated into Assertive Community Treatment (ACT) teams ${ }^{20,21}$, intensive case management services ${ }^{22,23}$, psychiatric emergency rooms, and inpatient units, where they are likely to encounter consumers experiencing major mental health crises with the attendant florid symptomatology. Such involvement of peers has contributed to the reduction of coercive interventions, involuntary admissions, and self-harming behaviors ${ }^{18}$.

For a vulnerable group, such as individuals being discharged from inpatient care, the employment of PSWs adds a potent ingredient to help bridge the gap between hospitaland community-based services, resulting in better engagement and satisfaction with services ${ }^{24,25}$.

The ability of PSWs to serve as a role model for their peers going through crises and adjustments in the community has been demonstrated frequently over the past 20 years $^{20,26-28}$. With the benefit of specifically developed training programs, combined with personal experiences as psychiatric patients, PSWs have demonstrated that they can adequately perform in such jobs with a certain amount of support and without undue risk to their own mental health ${ }^{29,30}$. The employment of PSWs helps aligning services that are being offered with the concerns of those in need of such services and their supporters, resulting in greater engagement and benefits $\mathrm{s}^{25,31,32}$.

A unique role for peer workers in the promotion of individual recovery among their peers has been widely discussed and it is anticipated as a considerable benefit for service users in Latin America. This effect can be mediated in a variety of ways, both general and specific. For instance, such peers work toward promoting hope and optimism instead of the bleak outlook that has been portrayed by psychiatry for individuals suffering from serious disorders. They can model the possibility of recovery and regained functioning through their own examples; instruct their peers in specific self-help and coping strategies; and support a more effective engagement in health and mental health services ${ }^{25}$. Peer worker involvement in service provision has also been shown to enhance subjective quality of life in a number of key areas ${ }^{22}$.

Finally, the possibility that PSWs may serve as change agents in a mental health system that aims at transforming itself has to be seriously considered. Mental health professionals and paraprofessionals are likely to be influenced in positive ways if PSWs can prove their mettle and demonstrate their capacities in the field. We assume that some of the effects on clients in our study of peer specialists as members of intensive case management teams were mediated by changed attitudes and behaviors of the case managers' themselves ${ }^{22}$. 


\section{RATIONALE FOR INTRODUCING PEER SUPPORT WORKERS TO LATIN AMERICA AND OTHER LOW AND MIDDLE INCOME COUNTRIES}

Integrating specialized and experience-based knowledge would be an asset to any mental health system that seeks to broaden its benefits for service users by enhancing recovery, empowerment, and peer networks ${ }^{33,34}$. Fact is that, up to this point, virtually, all such positions have been created in developed countries, with the Anglophone contries leading the way (Canada, United States of America, United Kingdom, New Zealand, and Australia). Holland, Germany, Austria, and Sweden have followed the lead, while several Western European countries are either resisting (France), or have yet to develop their own ways of approaching this opportunity. Even though the World Network of Users and Survivors of Psychiatry incorporates individual members and organizations from many countries, including low and midle income countries (LMICs), only a small number of them have enabled former service users to become employed in support of their peers.

A recent development in primary healthcare services has been introducing lay workers into the workforce, either as community health workers ('service extenders') or as other types of basic service providers with considerably lower levels of education ${ }^{3}$. This strategy of 'task shifting' has been especially effective in African countries, which are greatly suffering from the HIV/AIDS epidemic and where medical specialists and other professional personnel are seriously lacking ${ }^{35}$. Compensating for such deficiencies by expanding post-secundary education would take a great deal of financial investment and time, by which point many people affected by HIV/AIDS might succumb to the disease. In contrast, task shifting offers a timely and efficacious solution, and people with other infectious diseases, minor injuries, and uncomplicated medical conditions that do not require surgery have also benefitted from this relatively quick and economical expansion of the workforce. Similar developments have happened in the field of substance abuse treatment, especially in Eastern Europe and Central Asia, where addiction and related diseases are widespread, and specialty care is often lacking.

Though the translation of these experiences into the mental health field of Latin America has yet to occur, the situation is progressing, and peer support in such region is currently being promoted by RedeAmericas, funded by a federal US grant. This planned research project (a randomized controled study of critical time intervention - task shifting - CTI-TS, which is a modification of the multiply replicated critical time intervention) combines the rationale of extending the service system via paraprofessional workers (CMHWs), with the added benefit of introducing experienced service users (PSWs) into uniquely created positions. In those positions, the PSWs will provide peer- and recovery-oriented services to people who have never been exposed to such opportunities. Introducing the special position of PSW is expected to lead to a synergistic combination of task shifting with the added value of personal experience.

The issue of whether the introduction of PSWs might have a reinforcing effect on the advocacy and self-help movement of current or former psychiatric patients has never been formally investigated. Nevertheless, it can be assumed that such opportunities would encourage some ex-patients who may hesitate to become involved. In New York, USA, for example, where peer worker positions have grown significantly over the past two decades, it is safe to say that the increasing number of training programs and job opportunities has enabled many people to step forward, who would otherwise have remained isolated and unlikely to apply their own experiences to others in similar predicaments. In Latin America, only Brazil has a well-formed and long established advocacy movement, composed of current or former service users, their friends and relatives, and a select number of mental health professionals, mostly working in academic domains ${ }^{36}$. It remains to be seen to what extent the introduction of PSWs into the mental health workforce of Brazil can further galvanize this movement, and whether former patients will rise to the occasion and demand additional opportunities, beyond the small number of positions to be created through RedeAmericas.

\section{SETTING THE STAGE FOR PEER SUPPORT IN LATIN AMERICA: LOCAL EXAMPLES FROM BRAZIL, ARGENTINA, AND CHILE}

Important developments have occurred in Brazil, Argentina, and Chile over the past two decades, which need to be considered while developing new roles for PSWs in the mental health system.

\section{Brazil}

As mentioned, Brazil has the most elaborate and widespread network of family and patient advocates in Latin America $^{36}$. This movement originated in affiliation to the antiinstitutional reform that was stimulated in the early 1980s by members of the Italian Democratic Psychiatry scene ${ }^{37}$. Franco Basaglia, the pater familias of the Italian psychiatric reform, visited Brazil on several occasions towards the end of his life and, according to many, had a powerful impact on the developments in this country. A national plan to reform mental health services, with emphasis on creating community 
mental health centers while gradually reducing the census of long-term inpatients and (possibly) closing some of the more remote institutions, has so far yielded more than 1600 such centers (Centro de Atenção Psicossocial - CAPS) across the entire country ${ }^{38,39}$. Along with this impressive development, akin to the CMHC-movement of the 1960s and 1970s in the USA, a strong advocacy movement (Movimiento Antimanicomial) has articulated its positions in several formats (national meetings, publications, etc.) over the past 15 years ${ }^{36,40}$.

Alongside this movement, Richard Weingarten, an American consumer advocate and former patient, visited and interviewed a number of Brazilian survivors, resulting in a collection of narratives that reflect individual experiences as well as the national advocacy movement ${ }^{41}$. Richard (see his article in this issue) has contributed a great deal to the connection between Brazilian self-help activists and developments in the US and elsewhere.

The Brazilian Ministry of Health charged Professor Eduardo Vasconcelos with the development of a manual for the establishment of mutual support and self-help groups by and for users and family members, which was recently published ${ }^{42}$. Relying on it, a number of ex-users are being trained to facilitate mutual support groups within and separate from community mental health services. Due to the relative lack of experience in this area, mixed groups of users, family members, and mental health workers/professionals are being trained in this methodology, so that they can support each other in this early phase of implementation. Facilitator positions are unpaid and, so far, only a limited number of groups have gotten off the ground. Vasconcelos envisions that facilitators will ultimately be reimbursed for their services, and positions of 'mental health coach' will be created, not unlike the positions of 'arts and crafts instructor', 'substance abuse technician,' or 'community health agent,' which have existed for a number of years in Brazi ${ }^{42}$.

\section{Argentina}

The situation in Argentina with respect to mental health reform is more complex, and a comprehensive policy has yet to be formulated at the national level. Recently, changes in the law overseeing institutional mental health care have been promulgated, which might affect the lives of people with psychiatric disabilties in more positive ways ${ }^{43}$. Argentinian mental institutions have been singled out for conditions that do not adequately protect the human rights of its residents ${ }^{44}$, which has galvanized a movement of legal advocacy to help improve the situation ${ }^{45}$. An outstanding example of a regional mental health reform took place in the Patagonian province of Rio Negro, where de-institutionalization has gone along with a series of community-based interventions, including mutual support and self-help groups ${ }^{46}$. Rio Negro model has attracted international attention, reflected in several World Health Organization (WHO) policy papers ${ }^{47}$. Along similar lines of local reform, the Instituto Austral de Salud Mental in Patagonia, under the leadership of psychiatrist Jose Lumerman, has developed exemplary practices in community-based rehabilitation and linkage to primary care ${ }^{48}$. In doing so, Lumerman and his team have prepared the ground for the establishment of task shifting and peer involvement in the mental health workforce, while engaging the medical and general community in this process.

One exceptional example of patient empowerment in the Argentinian mental health system that has attracted international attention is Radio La Colifata, a group-based radio transmission from La Borda hospital in Buenos Aires, one of the largest mental institutions in the country. This project was initiated by psychologist Alfredo Olivera in 1991, and though it has struggled to survive financially, it has certainly represented an avenue for articulating and broadcasting the views of psychiatric patients (including long-stay inmates) in a public frame.

Finally, Proyecto Suma in Buenos Aires has become one of the premier experimental programs where user participation is writ large, and the process of recovery is being considered from a variety of perspectives ${ }^{49,50}$. This exemplary program appears well-positioned to further advance in this progressive direction and to develop opportunities for user employment and new roles in and around the mental health system.

\section{Chile}

Similar to Brazil, but unlike to Argentina, Chile has been engaged in a process of undertaking mental health services reform at the national level over the past two decades. The emphasis was on improving the availability and accessibility of mental health services, while aiming at a significant reduction of long-term inpatient census ${ }^{51,52}$. A crucial step in the Chilean mental health reform was the formulation of a National Mental Health Plan in 1993 (further refined in 2000), which defined the model and the route that the policy was going to follow ${ }^{53,54}$.

Chilean policies have stressed the relevance of: primary care for the treatment of common mental disorders (depression and anxiety); specialized outpatient centers to support primary care teams and to treat people with severe mental disorders; day hospitals and psychiatric beds in general hospitals to manage acutely ill people and severe crises; and group homes to address the need for social supports for those with severe mental disability, enabling them to exert their rights 
to live in the community ${ }^{10}$. Among the key strategies applied during the following years were:

- developing mental health and psychiatric service networks, based on a sectorized and community-based model that combines several elements to provide comprehensive care for people in need and to ensure continuity of care for patients with low to high levels of complexity;

- designing programs that support the prioritization and implementation of resources toward mental disorders with the highest prevalence and social impact, which include severe mental disorders, focusing on depression, schizophrenia, and substance abuse/dependence; and

- Forming mutual help groups of patients and family members, with the intention of progressively integrating them in planning and evaluating the programs and interventions.

An important focus of the Chilean health system has been on establishing comprehensive community mental health centers with strong linkages to primary health care services ${ }^{51,55,56}$. Families and user organizations have been actively involved in this process, although little has been published about their independent activities, and with the emphasis placed on family members, the potential for user development has been left unclear. The notion of advocacy has found its way into the language of reform, while empowerment and recovery remain to be explored ${ }^{52}$.

\section{REDEAMERICAS RESEARCH DEMONSTRATION PROJECT - CRITICAL TIME INTERVENTION - TASK SHIFTING}

Within the context of the recently funded federal grant "Mental Health Hubs for Latin America" (grant \# NIMH1U19MH095718-01), it was decided to implement a randomized controlled trial of CTI-TS. This intervention is a modified version of CTI, which has been replicated in several countries with various target populations, including most recently in Rio de Janeiro ${ }^{57}$. It is a time limited, three-phased intervention, usually provided by one middle-level mental health worker, at a juncture where individuals are deemed most vulnerable (transition from homeless shelter to permanent housing; discharge from acute or long-term hospitaliztion; first episode of psychosis; particularly challenging situations with poor treatment adherence $)^{58,59}$. The primary goal of CTI-TS is to engage individuals with major mental health conditions (psychosis spectrum disorders) at the point of entry into the community care system. It is assumed that such individuals will be particularly vulnerable at this critical time of transition and may fail to make effective connections to the new services, while remaining symptomatic, dysfunctional, and as a burden to their families.

CTI-TS addresses a fundamental gap in mental health services in the urban areas of Latin America in several ways: it employs PSWs in a community-based service for people with psychoses, which is still rare in the Latin American context $^{8,60}$. CTI-TS (like the original CTI) is feasible for use in marginalized (as well as other) communities, which is essential for reaching the neediest people; it is tailored to overcome the challenge of limited resources in order to take advantage of an opportunity created by the policy environment in Latin America; the pilot regional of CTI-TS establishes the capacity for regional RCTs of task shifting interventions in Latin America.

The development of CTI-TS to address this gap was a joint effort of the three leading (Hub Latin America - HLA) sites (Federal University of Rio de Janeiro - UFRJ, University of Chile - UCH, and Columbia University Global Mental Health Program - CUGMHP). CTI-TS was based on CTI; investigators at UCH and CUGMHP (Valencia and Susser respectively) were its creators ${ }^{58,61}$, have been involved in its adaptation and testing in other contexts ${ }^{62-65}$, and were closely involved in all the UFRJ studies from their inception. UFRJ colleagues conducted a series of studies supported by grants from the Brazilian government: firstly, qualitative and quantitative studies of service users, their family members, and service providers at mental health clinics; then, adaptation and translation of CTI informed by these data; next, a pilot study, further adaptation, and a second pilot study $y^{66}$; and finally the formulation of CTI-TS. The pilot studies included the marginal communities of Rio de Janeiro, where approximately $28 \%$ of the city's population lives, and in which basic infrastructure such as transportation is lacking, formal jobs are scarce, and violence is endemic. The problems that we confronted in Rio are shared by many urban areas of the region, and CTI-TS was designed to be broadly applicable across these areas.

Based on a year-long process of planning, the intervention in a collaborative fashion, we expect CTI-TS to address this risky situation in the following manner: a team of two workers - a traditional CMHW and a PSW - will engage the consumer within three months of their enrollment, and begin to work with him/her in two areas at the same time: strengthening fledgling (or nonexistent) links to mental and physical health services, while offering support to the individual and their families (primary focus of the CMHW); and strengthening the recovery orientation of the individual consumer, while supporting him/her in making meaningful 
connections in the larger community beyond their homes (primary focus of the PSW).

It is hypothesized that this combined intervention will result in better connections to services, improved quality of life, enhanced communty integration, reduced family burden, and greater recovery orientation. The PSW will have a key role in this intervention, pairing off with the CMHW as well as interacting with the clinical treatment team at community mental health services. Thus, the role of the PSW is similar to the role of Peer Specialist in ICM and ACT teams ${ }^{22,67}$, however it is also distinct due to a more specific focus of the work and its phasic/time-limited course. The PSWs, given his/her specific expertise in managing their own recovery and navigating the mental health system, will be expected to provide hope and role modeling for the consumers, and also link them with normatizing community activities, such as leisure, sports, art, music, and more or less formal self-help groups.

\section{ANTICIPATED OBSTACLES AND OUTLOOK FOR THE FUTURE}

Challenges are likely to happen on several levels, especially due to the novelty of this approach and the near total lack of experiences in recruiting, hiring, training, and retaining PSWs in Latin America.

Recruitment will focus on two general directions: aiming at involving current or former patients within the services who are likely to participate in this project (including some in the neighboring catchment areas); and engaging with known activists either through existing support groups, advocacy organizations, or through personal acquaintances. The first method might lead to difficulties for the consumer who may be receiving services in the same clinic where he or she is likely to work. Relationships to their peers will undoubtedly be altered in ways that are hard to predict, both adversely and positively. Competition among users within the same service might ensue, as well as difficulties with former service providers who are now working as colleagues. There are several recent articles with specific recommendations that address some of these difficulties early on in order to avoid irreversible conflicts and other ongoing problems $\mathrm{s}^{28,29,68}$. More than likely, a broad outreach effort may yield a considerable number of more or less qualified candidates, and given the limited number of positions being offered at this time, it might leave many individuals high and dry with little hope for immediate employment. Therefore, it would make sense to begin developing similar positions outside of the RedeAmericas CTI-TS research project, if local funding can be made available.

Training the new PSWs will be another challenge, given that no such training has ever taken place in Latin America. Fortunately, there is a great deal of experience in training lower and middle-level community mental health (and general health) workers, especially in Brazil ${ }^{69}$. Integrating the CMHWs and PSWs into this existing framework will have several advantages (i.e. normalization, team-building, shared knowledge, etc.) without necessarily covering certain content areas that are specific to PSW. To address this deficiency, the project developers in Rio de Janeiro intend to engage with known activists in the early phases of the training in rder to see whether any of them could join the training team and cover some of these essential areas . Several training modules on recovery and peer support have been created in or translated into Spanish and may become useful in the trainings that are being developed for CTI-TS and RedeAmericas ${ }^{70,71}$. While there are by now many comprehensive training programs, ranging from a few days to several months, for peer support/peer specialist $^{6,30,72,73}$ these have taken many years to develop, and due to language and financial obstacles, they cannot easily be replicated in the new contexts. Consultation and technical support from known expert trainers from other countries are advised. It should be expected that developing a cadre of peer trainers will take a number of years, not unlike during the early phases of peer specialist projects in the US and elsewhere.

The response of the broader mental health system and provider groups to this novel intervention is hard to predict, due to the unique role of the RedeAmericas teams, which are at the forefront of public health and community mental health movements. More traditional providers, as well as unionized workers, might take a somewhat jaundiced view to these new roles for patients, which should be seen as an opportunity for community education, rather than a source of insurmountable conflict. It is worth noting that the US and several other countries are slowly, but surely, embracing this practice, even in areas that have traditionally been devoid of an advocacy and recovery orientation.

Hiring, integrating, and supervising these new workers will also present a challenge, especially given the unfamiliary of the various parties with their new roles and relationships. Some of these difficulties can be anticipated and addressed, using several recent publications as guidelines ${ }^{28,68}$. The issue of cooptation (i.e. usurpation and suppression of peer values by traditional services) has been raised by a number of 
consumer and former patient advocates and will be an ongoing concern, which can only be addressed through regular supervision and contact with independent peer support/ advocacy organizations.

Promoting a recovery orientation through the employment of PSWs alone is a risky strategy. Unless a broader buy-in into these novel concepts can be achieved, the PSWs might remain isolated in advancing these perspectives, and clients they are working with may potentially be trapped in conflicting orientations between peer workers and other clinicians. While there is a beginning literature in Spanish and Portuguese on defining and advancing recovery-oriented mental health services ${ }^{74}$, these developments are in their very early stages.

Ultimately, integrating peer workers into Latin American mental health services presents a unique opportunity that is likely to galvanize providers and self-help activists at the same time. The outcomes of this demonstration project will hopefully lead the way to broad integration and upscaling of peer support services within the three partner countries and across all Latin America.

\section{REFERENCES}

1. Clark DW. Community Prevention and Control. In: Clark DW, MacMahon B, eds. Preventive and Community Medicine. Boston: Little, Brown and Company; 1957. p. 97-105.

2. Geiger HJ. Community-oriented primary care: a path to community development. Am J Public Health. 2002;92(11):1713-6.

3. Lehmann U, Sanders D. Community health workers: What do we know about them? The state of the evidence on programmes, activities, costs and impact on health outcomes of using community health workers. [Internet]. Geneva: WHO, Evidence and Information for Policy, Department of Human Resources for Health Geneva; 2007. [cited 2102 Aug 11]. Available from: http://www.who.int/hrh/documents/ community_health_workers.pdf

4. Lewin SA, Dick J, Pond P, Zwarenstein M, Aja G, van Wyk B, et al. Lay health workers in primary and community health care. Cochrane Database Syst Rev. 2005;(1):CD004015.

5. Stoneking BC, McGuffin BA. A review of the constructs, curriculum and training data from a workforce development program for recovery support specialists. Psychiatr Rehab J. 2007;31(2):97-106.

6. Salzer MS, Katz J, Kidwell B, Federici M, Ward-Colasante C. Pennsylvania certified peer specialist initiative: Training, employment and work satisfaction outcomes. Psychiatr Rehab J. 2009;32(4):301-5.

7. Weingarten R. Brazil's mental health adventure. Psychiatr Rehabil J. 2003; 26(3):303-5.

8. Vasconcelos EM. Tipologia e desafios dos movimentos socials e dispositivos participativos e de empoderamento de usarios, familiars e trabalhadores no campo de saude mental no Brazil recente. Rio de Janeiro: Escola de Serviço Social da Universidade Federal do Rio de Janeiro; 2004.

9. Minoletti A, Sepulveda R, Horvitz-Lennon M. Twenty years of mental health policies in Chile: lessons and challenges. Int J Mental Health. 2012. In press.

10. Davidson L, Chinman M, Sells D, Rowe M. Peer support among adults with serious mental illness: a report from the field. Schizophr Bull. 2006;32:443-50.

11. White WL. Peer-based Addiction Recovery Support: History, Theory, Practice, and Scientific Evaluation. Great Lakes Addiction Technology Transfer Center \& Philadelphia Department of Behavioral Health and Mental Retardation Services. [Internet]. 2009. [cited 2012 Aug 10]. Available from: http://www.oregon.gov/OHA/amh/recovery/peeraddiction-recovery-support.pdf?ga $=\mathrm{t}$
12. Allen HA, Carpenter D, Sheets JL, Miccio S, Ross R. What do consumers say they want and need during a psychiatric emergency? J Psychiatr Pract. 2003;9:39-58.

13. Peer counselors support consumers in emergency rooms [Internet] MIWatch.org; 2012. [cited 2012 Aug 9]. Available from: http://www. miwatch.org/2010/08/peer_counselors_support_consumers_in_ emergency_room.html

14. Coatsworth-Puspoky R, Forchuk C, Ward-Griffin C. Peer support relationships: an unexplored interpersonal process in mental health. J Psychiatr Ment Health Nurs. 2006; 13(5):490-7.

15. Hardiman ER, Jaffee EM. Outreach and peer-delivered mental health services in New York City following September 11, 2001. Psychiatr Rehabil J. 2008; 32(2):117-23.

16. Burns-Lynch B, Salzer MS. Adopting innovations--lessons learned from a peer-based hospital diversion program. Community Ment Health J. 2001; 37(6):511-21.

17. Ashcraft L, Anthony WA. Crisis services in the 'living room. Behav Healthc. 2006; 26(7):12-4

18. Greenfield TK, Stoneking BC, Humphreys K, Sundby E, Bond J. A randomized trial of a mental health consumer-managed alternative to civil commitment for acute psychiatric crisis. Am J Community Psychol. 2008; 42(1-2):135-44.

19. Robinson J, Bruxner A, Harrigan S, Bendall S, Killackey E, Tonin V, et al. Study protocol: The development of a pilot study employing a randomized controlled design to investigate the feasibility and effects of a peer support program following discharge from a specialist first-episode psychosis treatment centre. BMC Psychiatry. 2010;10:37-44.

20. Dixon L, Hackman A, Lehman A. Consumers as staff in assertive community treatment programs. Adm Policy Ment Health. 1997; 25(2):199-208.

21. Clarke GN, Herinckx HA, Kinney RF, Paulson RI, Cutler DL, Lewis $\mathrm{K}$, et al. Psychiatric hospitalizations, arrests, emergency room visits, and homelessness of clients with serious and persistent mental illness: findings from a randomized trial of two ACT programs vs. usual care. Ment Health Serv Res. 2000; 2(3):155-64.

22. Felton CJ, Stastny P, Shern DL, Blanch A, Donahue SA, Knight E, et al Consumers as peer specialists on intensive case management teams: impact on client outcomes. Psychiatr Serv. 1995; 46(10):1037-44. 
23. Rivera JJ, Sullivan AM, Valenti SS. Adding consumer-providers to intensive case management: does it improve outcome? Psychiatr Serv. 2007;58(6):802-9.

24. Lucksted A, McNulty K, Brayboy L, Forbes C. Initial Evaluation of the Peer-to-Peer Program. Psychiatr Serv. 2009;60(2):250-3.

25. Fukui S, Davidson LJ, Holter MC, Rapp CA. Pathways to Recovery (PTR): Impact of peer-led group participation on mental health recovery outcomes. Psychiatr Rehab J. 2010;34(1):42-8.

26. Mowbray CT, Chamberlain P, Jennings M, Reed C. Consumer-run mental health services: results from five demonstration projects. Community Ment Health J. 1988;24(2):151-6.

27. Simpson EL, House AO. Involving users in the delivery and evaluation of mental health services: systematic review. BMJ. 2002; 325(7375):1265. Review.

28. Chinman M, Lucksted A, Gresen R, Davis M, Losonczy M, Sussner B, et al. Early experiences of employing consumer-providers in the VA. Psychiatr Serv. 2008;59(11):1315-21.

29. Gates LB, Akabas SH. Developing strategies to integrate peer providers into the staff of mental health agencies. Adm Policy Ment Health. 2007; 34(3):293-306.

30. Katz J, Salzer M. Certified Peer Specialist training program descriptions. UPenn Collaborative on Community Integration. [Internet]. 2006. [cited 2102 Aug 11]. Available from: http://www.vermontrecovery.com/files/ Download/PeerSpecialistProgramDescriptions.pdf

31. Vasconcelos EM. Do hospício à comunidade: mudança sim; negligência não. Belo Horizonte: Segrac; 1992.

32. Mosquera M, Zapata Y, Lee K, Arango C, Varela A. Strengthening user participation through health sector reform in Colombia: a study of institutional change and social representation. Health Policy Plan. 2001; 16(2):52-60.

33. Davidson L, Tondora J, O’Connell MJ, Kirk T Jr, Rockholz P, Evans AC. Creating a recovery-oriented system of behavioral health care: moving from concept to reality. Psychiatr Rehabil J. 2007;31(1):23-31.

34. Olmos-Gallo PA, Starks R, Lusczakoski KD, Huff S, Mock K. Seven key strategies that work together to create recovery based transformation. Community Ment Health J. 2011. [Epub ahead of print].

35. Zachariah F, Ford N, Philips M, Lynch S, Massaquoi M, Janssens V, et al. Task shifting in HIV/AIDS: opportunities, challenges and proposed actions for sub-Saharan Africa. Trans R Soc Trop Med Hyg. 2009; 103(6):549-58.

36. Vasconcelos EM. Derechos y empoderamiento (empowerment) de usuários y familiares en el terreno de la salud mental, y su difusión en países de origen latino. Átopos. 2001;11:23-44.

37. Fusar-Poli P, Bruno D, Machado-De-Sousa JP, Crippa J. Franco Basaglia (1924--1980): three decades (1979--2009) as a bridge between the Italian and Brazilian mental health reform. Int J Soc Psychiatry. 2011; 5(1):100-3.

38. Costa NR, Siqueira SV, Uhr D, Silva PF, Molinaro AA. [Psychiatric reform, federalism, and the decentralization of the public health in Brazil]. Cienc Saúde Col. 2011;16(12):4603-14.

39. Pitta AM. [An assessment of Brazilian psychiatric reform: institutions, actors and policies]. Cienc Saúde Col. 2011;16(12):4579-89.

40. Lüchmann LH, Rodrigues J. O movimento antimanicomial no Brasil [The anti-asylum movement in Brazil]. Cienc Saúde Col. 2007;12(2):399-407.
41. Vasconcelos EM, Cavalcante Paes Leme CC, Weingarten R, Novaes PR. Reinventando a vida. Narrativas de recuperacao e convivencia com o trastorno mental. Rio de Janeiro: EncantArte; 2005.

42. Vasconcelos EM. Manual de ajuda e suporte mutuos em saude mental. Brasília: Ministerio de Saude; 2011.

43. Martínez Ferretti JM. [Legal framework of psychiatric hospitalization in Buenos Aires regarding laws 22914 and 448]. Vertex. 2006; 17(65):35-42.

44. Washington DC. Ruined lives: segregation from Society in Argentina's Psychiatric Asylums: Disability Rights International; 2007. [Internet]. [cited 2012 Aug 11]. Available from: http://www.disabilityrightsintl.org/ wordpress/wp-content/uploads/MDRI.ARG.ENG.NEW-Argentina.pdf

45. Buenos Aires, Argentina. La Cámara de Diputados dio media sanción al proyecto de ley nacional de salud mental. Centro de Estudios Legales y Sociales; 2009. [Internet]. Spanish. [cited 2012 Aug 12]. Available from: http://www.cels.org.ar/documentos/?info=detalleDoc\&ids=3\&lang=es \&ss $=\& i d c=1174$

46. Cohen H, Natella G. Argentina: el programa de salud mental en la provincia Rio Negro. In: Rodríguez J, ed. Salud Mental en la Comunidad. Washington: PALTEX, PAHO; 2009. p. 357-78.

47. Collins PY. Waving the banner of the mental health revolution: Psychiatric reform and community mental health in the Province of Rio Negro, Argentina. In: Caldas de Almeida JM, Cohen A, eds. Innovative Community Mental Health Services in Latin America and the Caribbean. Washington, D.C.: PAHO; 2008. p. 1-32.

48. Collins PY, Lumerman J, Conover S, Susser E. Using local resources in Patagonia: A model of community-based rehabilitation. Int J Men Health. 1999;28(3):17-24

49. Agrest M, Druetta I. El concepto de recuperación: la importancia de la perspectiva y la participación de los usuarios. VERTEX Rev Arg Psiquiat. 2011;12:56-64

50. Ardila S. La inclusión de la perspectiva de los usuarios en los servicios de salud mental. Vertex. 2011;22(95):49-55.

51. Zaccaria A, Minoletti A. Plan nacional de salud mental en Chile: 10 años de experiencia. Rev Panam Salud Pública. 2005;18(4-5):346-58.

52. Minoletti A. Abogacía para mejorar las políticas públicasen salud mental en Chile. Átopos. [Internet] 2011;(11):84-93. [cited 2012 Aug 12]. Available from: http://www.atopos.es/pdf_11/84-93 Abogac\%C3\%ADa\%20para\%20mejorar.pdf

53. Pemjean A. El proceso de reestructuración de la atención en salud mental y psiquiatría en Chile (1990-1996). Cuad Med Soc. 1996;37:5-17.

54. Minoletti A. Perspectivas de desarrollo de la salud mental en Chile en el siglo XXI. Rev Psiquiatr. 2003;19:88-98.

55. Funk M, Minoletti A, Drew N, Taylor J, Saraceno B. Advocacy for mental health: Roles for consumer and family organizations and governments. Health Promot Int. 2005;2(1):70-5.

56. Alvarado R, Minoletti A, Torres González A, Moreno Küstner B, Madariaga C, Sepúlveda A. Development of community care for people with schizophrenia in Chile. 2012. in press.

57. Cavalcanti MT, Carvalho MC, Valência E, Dahl CM, Souza FM. Adaptação da "Critical Time Intervention" para o contexto brasileiro e sua implementação junto a usuários dos centros de atenção psicossocial do município do Rio de Janeiro. Cienc Saúde Col. 2011;16(12):4635-42.

58. Susser E, Valencia E, Conover S, Felix A, Tsai WY, Wyatt RJ. Preventing recurrent homelessness among mentally ill men: a" critical time" 
intervention after discharge from a shelter. Am J Public Health. 1997; 87(2):256-62.

59. Herman D, Opler L, Felix A, Valencia E, Wyatt RJ, Susser E. A critical time intervention with mentally ill homeless men: impact on psychiatric symptoms. J Nerv Ment Dis. 2000; 188(3):135-40.

60. Delgado-Gallego ME, Vazquez-Navarrete L. Barreras y oportunidades para la participación social en salud en Colombia: percepciones de los actores principales. Rev Salud Pública. 2006;8(2):128-40.

61. Valencia E, Susser E, Torres J, Felix A, Conover S. Critical time intervention for homeless mentally ill individuals in transition from shelter to community living. In: W. B, J. T, eds. Mentally Ill and Homeless: Special Programs for Special Needs. Newark, NJ: Gordon and Breach Science Publishers; 1997. p. 75-94.

62. Herman D, Conover S, Draine J. Critical time intervention. In: Rubin A, Springer D, eds. Psychosocial Treatment of Schizophrenia. Hoboken, NJ: John Wiley \& Sons, Inc.; 2010.

63. Draine J, Herman DB. Critical time intervention for reentry from prison for persons with mental illness. Psychiatr Serv. 2007;58(12):1577-81.

64. Valencia E, Van Hemert AM, Van Hoeken D, Van der Plas A. Gestructureerde zorgtoeleiding met. Crit Time Interv Soc Psych. 2006;78:41-7.

65. Kasprow WJ, Rosenheck RA. Outcomes of critical time intervention case management of homeless veterans after psychiatric hospitalization. Psychiatr Serv. 2007;58(7):929-35.

66. Cavalcanti MT, Dahl CM, de Carvalho MCA, Valencia E. Criteria for admission and continuity of health care in psychosocial healthcare services, City of Rio de Janeiro, Southeastern Brazil. Rev Saúde Pública. 2009;43(1):1-6.
67. Dixon L, Goldberg R, Iannone V, Lucksted A, Brown C, Kreyenbuhl J, et al. Use of a critical time intervention to promote continuity of care after psychiatric inpatient hospitalization. Psychiatr Serv. 2009; 60(4):451-8.

68. Gates LB, Mandiberg JM, Akabas SH. Building capacity in social service agencies to employ peer providers. Psychiatr Rehabil J. 2010; 34(2):145-52.

69. Vieira M, Durao AV, Raposo Lopez M. Para além da comunidade: trabalho e qualificação dos agentes comunitários de saúde. [Internet]. Rio de Janeiro: Escola Politécnica de Saúde Joaquim Venâncio/Fiocruz; 2011. [cited 2012 may 8]. Available from: http://www.fiocruz.br/media/ livro_epsjv.pdf

70. Spaniol L, Koehler M, Hutchinson D. Recuperando la esperanza, Libro practico. In: Restrepo-Toro ME, editor. Boston, MA: Center for Psychiatric Rehabilitation, Sargent College for Health and Rehabilitation Sciences, Boston University; 1999.

71. Restrepo-Toro ME. Entrecruzando nuestros caminos. Entrenamiento para companeros-promotores de recuperacion y rehabilitacion. Boston, MA: Boston University Center for Psychiatric Rehabilitation; 2010.

72. Repper J, Carter T. A review of the literature on peer support in mental health services. J Ment Health. 2011; 20(4):392-411.

73. NY. Peer Bridger Project [Internet]. New York: Troy Web Consutling; 2010. [cited 2012 Apr 12]. Available from: http://www.nyaprs.org/peerservices/peer-bridger/

74. Saavedra M, Francisco J. Cómo encontrar un lugar en el mundo: explorando experiencias de recuperación de personas con trastornos mentales graves. Hist Cienc Saúde. 2011;18(1):121-39.

Received on: 27/04/2012 Accepted on: 02/08/2012 